Pak. J. Agri., Agril. Engg., Vet. Sci., 2020, 36 (1): 13-20

ISSN: 1023-1072 (Print), ISSN: 2663-7863 (Online)

https://doi.org/10.47432/pjaaevs.2020.36.1.3

\title{
EVALUATION OF ORGANIC AMENDMENTS AND INSECTICIDES AGAINST OKRA YELLOW VEIN MOSAIC VIRUS AND ITS VECTOR
}

\author{
A. Munir ${ }^{1}$, S. Ali ${ }^{1}$, M. A. Zeshan ${ }^{\star 2}$, M. U. Ghani ${ }^{3}$ and A. A. Khan ${ }^{2}$ \\ ${ }^{1}$ Department of Plant Pathology, University of Agriculture, Faisalabad, Pakistan \\ ${ }^{2}$ Department of Plant Pathology, College of Agriculture, University of Sargodha, Sargodha, Pakistan \\ ${ }^{3}$ Institute of Soil and Environmental Sciences, University of Agriculture, Faisalabad, Pakistan
}

\begin{abstract}
Okra (Abelmoschus esculentus L.) is susceptible to number of diseases like Yellow Vein Mosaic Virus disease, Damping Off, Fusarium wilt, Powdery Mildew and Enation Leaf Curl. The Okra is favorite host of whitefly which transmits the okra Yellow Vein Mosaic Virus (OYVMV). OYVMV disease causes considerable yield losses in Okra. Experiment was conducted to check the efficacy of organic matter (poultry manure, leaves) and insecticides (Acetamiprid, Diafenthiuron, Pyridine Carboxamide) against OYVMV and its whitefly vector. In this experiment, ten okra varieties were sown in randomized complete block design (RCBD). Organic matter and insecticides were applied at recommended doses (@5ml/L) on weekly intervals. Among insecticides, Acetamiprid showed the best result to manage whitefly infestation with $60.01 \%$ mortality and OYVMV disease severity with $53.98 \%$ efficiency. Polo (Diafenthiuron) also showed good results to manage whitefly (56.36\%) and OYVMVD (46.34\%), but Ulala (Pyridine Carboxamide) insecticide was least effective to control whitefly population $(47.27 \%)$ and to manage the infection of OYVMV disease $(43.91 \%)$. Leaf manure was more effective with $61.16 \%$ efficiency as compared to poultry manure $(56.01 \%)$ against OYVMV disease severity. New chemistry insecticide (acetamiprid) gave the most effective control of whitefly and transmission of OYVMV and could be used in place of conventional insecticides. Leaf manure proved significant defense activator in okra plants with effective control of disease and could be used as eco-friendly management approach.
\end{abstract}

Keywords: insecticides, nutrients, OYVMV, plant defense, vector

\section{INTRODUCTION}

Okra (Abelmoschus esculentus L.) is the most important summer vegetable crop (Rahim and Dawar, 2015) which is cultivated in many countries of the world (Khan et al., 2013). It belongs to family Malvaceae. Pakistan ranked at 6th number in okra production which is 113270 tons per year (FAO, 2018). Okra is best antioxidant and its mucilage can be used for medicinal purpose (Roy et al., 2015). It can also be used for industrial applications (Akinyele and Temikotan, 2007). Okra is susceptible to various diseases like Damping Off, Enation Leaf Curl, Fusarium wilt, Okra Yellow Vein Mosaic disease (OYVMD) and Powdery mildew (Amadi et al., 2014). Okra leaf curl virus (OLCV), and okra enation leaf curl virus (OELCV) are the most prevalent pathogens from begomovirus genus other than OYVMV (Mishra et al., 2017). Among

"Corresponding author: ahmd_1566@yahoo.com viral diseases, OYVMD is responsible for more than $50 \%$ yield losses in okra (Mubeen et al., 2017). The OYVMD was first time reported in 1924 in India (Kulkarni, 1924). The causal agent of this disease is Okra Yellow Vein Mosaic Virus (Chaudhary et al., 2017). The OYVMV is transmitted by an insect vector whitefly (Bemisia tabaci) (Nagaraju et al., 2015). The early symptoms appear as diffused mottling on leaves with vein clearing near leaf margin. The vein clearing turns into vein chlorosis as the disease progresses (Chaudhary et al., 2017). Small leaves, stunted growth and malformed fruits are also characteristic symptoms of the disease (Venkataravanappa et al., 2012). Whitefly population and OYVMV disease incidence is less in cooler months than hot and dry weather (Sanwal et al., 2016).

Whitefly transmits OYVMV in healthy plants that are cause of the disease. To get rid from the causes of disease, vector control is mostly relied upon that is accomplished by insecticides 
application (Pagire et al., 2017). Synthetic chemicals are quick source to manage the OYVMV but it is not eco-friendly due to its residual long term bad effects (Chaitanya and Kumar, 2018). Suitable and timely application of Cyfluthrin and methamidophos resulted in significant whitefly mortality (Afzal et al., 2002). Significant whitefly mortality was recorded from carbofuran and malathion treated crops (Sharma et al., 2017). The yellow mosaic disease incidence was minimized where oxydimehon methy and carbofuron were sprayed against whitefly infestation (Saurabh et al., 2016). Whitefly has developed resistance against organophosphates and carbamates due to their repeated application (Thumar et al., 2018). New chemistry insecticides (neonicotenoids) are environmentally safe and no insect resistance is developed due to their unique mode of action (Acharya et al., 2002).

As the virus affects plant growth by disturbing plant physiology, the resulting damages can be repaired by using growth enhancers. Organic matter (leaves manure and poultry manure) improves soil health that strengthens plant anchorage and its ability to absorb nutrients for increased plant growth (Calvo et al., 2014). Dry leaves increase the plant defense against biotic stresses by enhancing enzyme activities (Sana et al., 2015). OYVMV disturbs the plant physiology in the form of chlorosis and mosaic; use of poultry manures provides with nutrients which boost the photosynthesis process (Riyana et al., 2018). Organic amendments (leaves and poultry manure) may enhance the okra plants immunity against OYVMV and the insecticides with varied mode of action would be beneficial for whitefly control and spread of OYVMV. The OYVMV was selected because it causes more losses than other begomoviruses in okra. The present study was focused to evaluate organic matter and non-conventional insecticides and against OYVMV disease and whitefly.

\section{MATERIALS AND METHODS \\ Experimental plan}

The trial was performed in the field of Plant Pathology Department, University of Agriculture, Faisalabad (UAF). Ten varieties (Suraksha F1, Raksha-14, G-Ho-2, OH-841, K-HO-2, Lakshmee, OK-409, Rupa-14, OK-Marvi, OKNayab) were sown in randomized complete block design (RCBD). Seeds of these varieties were collected from the Vegetable Research Institute, Ayub Agricultural Research Institute,
Faisalabad. Each variety was planted in six rows sub-plots with row-row $60 \mathrm{~cm}$ and plant-plant 20 $\mathrm{cm}$ spacing.

\section{Confirmation of virus through whitefly inoculation}

Two plants of each variety were also sown under diseased free area (net house) and other plants of each variety were grown in open field. After 25 days of sowing whiteflies were collected from the infected plants in the field with the help of aspirator and allowed to feed on healthy plants in net-house. These infected plants served source of virus inoculation through whitefly. The whiteflies were collected early in the morning. Symptoms were observed after 3-4 days.

\section{Data recording}

OYVMV confirmation in net-house was followed by data recording from diseased field. The disease severity data was recorded on the basis of symptomology (mosaic, chlorosis, and reduced leaf size). The data was recorded by using following formula:.

Diease severity $=\frac{\text { Number of infected leaves }}{\text { Total number of leaves }} X 100$

For whitefly data recording, three plants were selected randomly. After counting number of whiteflies from lower, middle and upper leaves, average was calculated.

\section{Collection of organic matter}

Organic material such as fallen leaves of the different trees was taken from the campus of UAF. The fallen leaves were collected from Shisham (Dalbergia sisso), Eucalyptus (Eucalyptus globules), and Neem (Azadirachta indica). Poultry manure (PM) was also collected from poultry farm of UAF. The fallen leaves were properly decomposed by placing them in polythene bags. After 15 days of decomposition, these were used for organic amendments. The decomposed leaves and poultry manure were applied in okra field before sowing separately @ $1 \mathrm{~kg} \mathrm{row}^{-1}$.

\section{Evaluation of different chemicals against OYVMV and its vector}

Different insecticides were sprayed against whitefly and for reduction of disease severity. The crop was sprayed at 7 days intervals. The three treatments were used at random in each block on okra varieties. The dosages given in 
the table are based upon per acre treatments which were adjusted according to the plot size. Usually 100 liters of water was sprayed in 1 acre @ 20 liters/tank. The total package of one acre divided and dissolved in each tank to cover the whole area.

\begin{tabular}{|l|l|l|}
\hline Serial No. & Treatments & Dose \\
\hline $\mathrm{T}_{1}$ & $\begin{array}{l}\text { Acetamiprid } \\
\text { (Neonicotinoid) }\end{array}$ & $@ 80 \mathrm{gm} /$ acre \\
\hline $\mathrm{T}_{2}$ & Polo (Diafenthiuron) & $@ 200 \mathrm{ml} /$ acre \\
\hline $\mathrm{T}_{3}$ & $\begin{array}{l}\text { Ulala (Pyridine } \\
\text { carboxamide) }\end{array}$ & $@ 60 \mathrm{gm} / \mathrm{acre}$ \\
\hline
\end{tabular}

\section{Statistical analysis}

The crop was sprayed at 7 days intervals. All data of YVMV and whitefly population as influenced by chemical application was statistically analyzed. All possible interactions were determined through ANOVA and the treatment means were compared by LSD test at $5 \%$ level of probability (Steel et al., 1997).

\section{RESULTS}

The data was collected for evaluation of organic matter and different insecticides to control whitefly and yellow mosaic virus disease on 10 okra varieties. Organic amendments (leaves manure, poultry manure), showed significant reduction in managing OYVMD in all varieties (Figure 1). Among organic amendments, leaf manure indicated the best results as compared to poultry manure and untreated control in all varieties. Minimum disease severity (16.32\%) was recorded in Lakshmee variety, followed by OK-Nayab (19.54\%) in leaf manure treated plants. There was significant difference between Lakshmee and OK-Nayab in response to disease severity against leaf manure. Maximum disease severity due to leaf manure application was recorded in Rupa-14, followed by K-Ho-2 where $27.38 \%$ and $25.83 \%$ disease severity was found, respectively. The difference of disease severity in Rupa-14, and K-Ho-2 was significant. Leaf manure was more effective as compared poultry manure and untreated control. The overall disease severity in leaf manure treated plants was $20.61 \%$ (Table 1 ). Leaf manure was $61.16 \%$ more efficient in managing the OYVMVD as compared to control.

Poultry manure also showed good results as compared to untreated control in all varieties. The most efficient disease control due to poultry manure was recorded in variety Lakshmee which exhibited (18.29\%) disease severity followed by OK-Nayab that gave $21.23 \%$ disease severity. Maximum disease severity and minimum efficiency of poultry manure was recorded in Rupa-14 (28.73\%), followed by OK409 (27.09\%). All the varieties showed significant difference in response to both treatments. The disease severity recorded in poultry manure treated plants was $23.35 \%$ (Table 1). Poultry manure gave $56.01 \%$ efficient management of OYVMVD.

Results revealed that Acetamiprid showed the best result in reducing the severity of OYVMV due to maximum control of whitefly in all the varieties with $23.01 \%$ disease severity (Table 2). Polo (Diafenthiuron) also showed good results in reducing OYVMV disease severity (26.82\%) but Ulala (Pyridine Carboxamide) was least effective with $(28.05 \%)$ as compared to control (50.00\%). Acetamiprid depicted $53.98 \%$ efficiency in managing OYVMV disease, followed by Polo (46.34\%), and Ulala (43.91\%).

In acetamiprid treated plants, OK-Nayab gave maximum OYVMV disease reduction with $8.32 \%$ disease severity, followed by $\mathrm{K}-\mathrm{Ho}-2$ that showed $10.38 \%$ disease severity (Figure 2). Minimum disease reduction due to acetamiprid was recorded in variety Lakshmee which showed $17.23 \%$ disease severity, followed by OK-Marvi (15.72\%). Polo (Diafenthiuron) depicted maximum reduction in severity of OYVMV disease in all varieties after acetamiprid. Minimum disease severity due to Polo (Diafenthiuron) was showed by OK-Nayab $(11.55 \%)$ maximum by Lakshmee (19.56\%). There was significant difference of disease severity between all the varieties in response to each treatment.

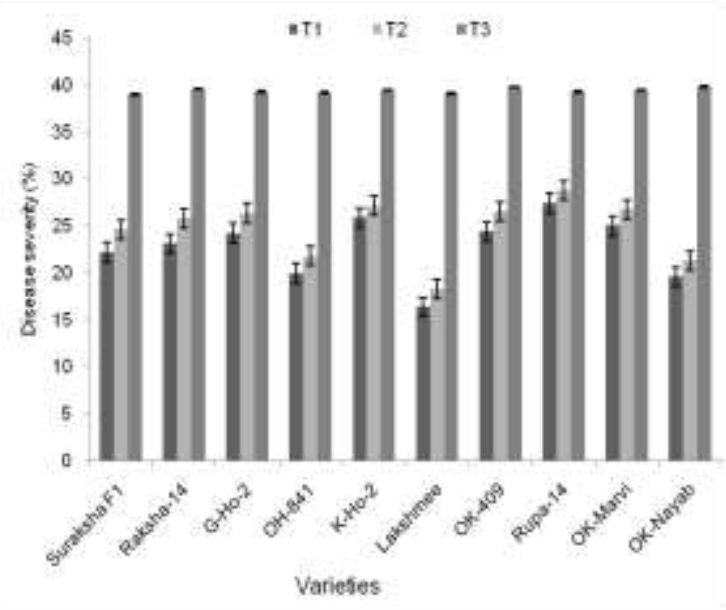

Figure 1. Evaluation of organic amendments against OYVMV disease severity recorded on different varieties $T_{1}$ (Leaves manure), $\mathrm{T}_{2}$ (Poultry manure), $\mathrm{T}_{3}$ (Control) 
Table 1. Efficiency of organic amendments against OYVMV disease severity

\begin{tabular}{|l|l|l|l|}
\hline $\begin{array}{l}\text { Serial } \\
\text { No. }\end{array}$ & Treatments & $\begin{array}{l}\text { Disease } \\
\text { severity (\%) }\end{array}$ & $\begin{array}{l}\text { Efficiency } \\
(\%)\end{array}$ \\
\hline $\mathrm{T}_{1}$ & Leaves manure & $20.61 \mathrm{c}$ & 61.16 \\
\hline $\mathrm{T}_{2}$ & Poultry manure & $23.35 \mathrm{~b}$ & 56.01 \\
\hline $\mathrm{T}_{3}$ & Control & $53.07 \mathrm{a}$ & -- \\
\hline $\mathrm{LSD}=1.23$ Different letters in column indicate significantly different values
\end{tabular}

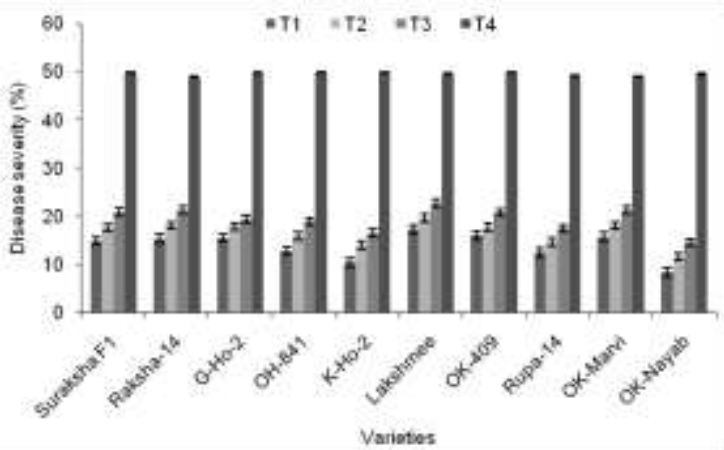

Figure 2. Evaluation of insecticides against OYVMV disease severity recorded on different varieties $T_{1}$ (Acetamiprid), $T_{2}$ (Polo), $\mathrm{T}_{3}$ (Ulala), $\mathrm{T}_{4}$ (Control)

Table 2. Efficiency of insecticides against OYVMV disease severity

\begin{tabular}{|l|l|c|c|}
\hline $\begin{array}{l}\text { Serial } \\
\text { No. }\end{array}$ & Treatments & $\begin{array}{c}\text { Disease } \\
\text { severity (\%) }\end{array}$ & $\begin{array}{c}\text { Efficiency } \\
(\%)\end{array}$ \\
\hline $\mathrm{T}_{1}$ & Acetamiprid & $23.01 \mathrm{~d}$ & 53.98 \\
\hline $\mathrm{T}_{2}$ & Polo (Diafenthiuron) & $26.82 \mathrm{c}$ & 46.34 \\
\hline $\mathrm{T}_{3}$ & $\begin{array}{l}\text { Ulala (Pyridine } \\
\text { Carboxamide) }\end{array}$ & $28.05 \mathrm{~b}$ & 43.91 \\
\hline $\mathrm{T}_{4}$ & Control & $50.00 \mathrm{a}$ & \\
\hline
\end{tabular}

$\mathrm{LSD}=1.47$ Different letters in column indicate significantly different values

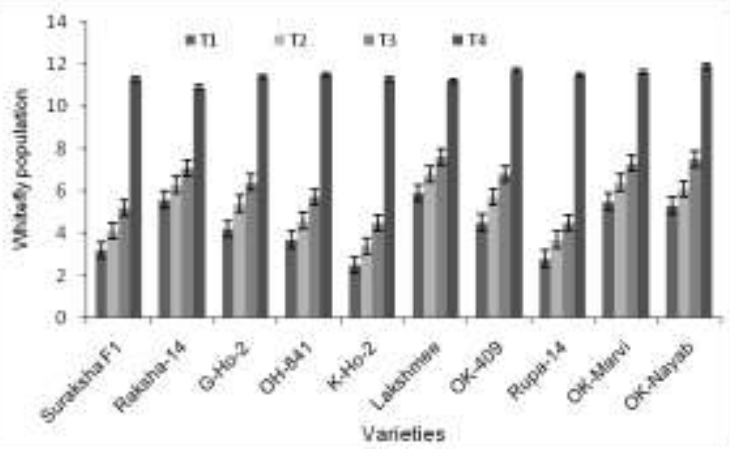

Figure 3. Evaluation of insecticides against whitefly recorded on different varieties $\mathrm{T}_{1}$ (Acetamiprid), $\mathrm{T}_{2}$ (Polo), $\mathrm{T}_{3}$ (Ulala), $\mathrm{T}_{4}$ (Control)

In the control of whitefly, all the insecticides significantly reduced whitefly infestation (Table 3). Acetamiprid was appeared to be most effective with mean whitefly population (3.4) as compared to Polo (4.8) and Ulala (5.8) in all the varieties as compared with control (11.00). Acetamiprid showed $62.01 \%$ efficiency in controlling whitefly population, followed by Polo $(56.36 \%)$ and Ulala (47.27\%). Minimum whitefly population was recorded in acetamiprid treated plants (2.5) and highest in Lakshmee (5.9). Polo (Diafenthiuron) gave maximum control of whiteflies in variety (K-Ho-2) 3.4 and Ulala (Pyridine Carboxamide) in 4.5. The response of all varieties against whitefly was significant in all treatments.

Table 3. Efficiency of insecticides against whitefly infestation

\begin{tabular}{|l|l|l|l|}
\hline $\begin{array}{l}\text { Serial } \\
\text { No. }\end{array}$ & Treatment & $\begin{array}{l}\text { Whitefly } \\
\text { population }\end{array}$ & $\begin{array}{l}\text { Efficiency } \\
(\%)\end{array}$ \\
\hline$T_{1}$ & Acetamiprid & 3.4 & 62.01 \\
\hline$T_{2}$ & Polo (Diafenthiuron) & 4.8 & 56.36 \\
\hline$T_{3}$ & Ulala & 5.8 & 47.27 \\
\hline$T_{4}$ & Control & 11.00 & \\
\hline
\end{tabular}

\section{DISCUSSION}

Ten okra varieties were sown to check the efficacy of organic matter and different insecticides against OYVMV and its vector (whitefly) population with the comparison to the untreated control. Organic matter (leaves and poultry manure) was effective against OYVMV. The leaf manure provide ease in the provision of soil nutrients that otherwise trigger the plant defense mechanism resulting in enhanced resistance against biotic stresses (Sana et al., 2015). In yellow mosaic disease, virus destroys the chlorophyll formation leading to yellowing of leaves. Leaf manure increase the activity of chlorophyll by producing enzymes (Kasai, 2008). The incorporation of leaf manure into the soil results in enhanced availability of nitrogen $(\mathrm{N})$ (Singh et al., 2014). The nutrient balance of the plants is disturbed by the pathogenic attack; in such conditions plants require nutrients for smoothing functioning of defense mechanisms. The provision of $\mathrm{N}$ to the stressed plants from any source increases the constitutive and induced defense (Mur et al., 2017). Mosaic and chlorosis are the salient symptoms of OYMVD; which indicate destruction of chloroplast cells and chlorophyll. Leaf manure provide $\mathrm{N}$ that is the main component of the chlorophyll and helps in managing the losses (Bassi et al., 2018). The application of poultry manure also increases $\mathrm{N}$ content in soil which helps the plant to manage the losses incurred by the virus infection (Agyarko et al., 2006). Fajinmi and Odebode (2005) applied organic manures against plant viruses in horticultural crops. Hassan et al. (2013) recorded significant disease reduction caused by whitefly transmitted begmoviruses in soils amended with poultry litter. Poultry manure contains many nutrients and growth regulators which affect plant growth and accelerate its 
immunity against several biotic and abiotic stresses (Yadav et al., 2017). Poultry manure provides the soil with NPK that are helpful in the production different phytoalexins to combat with pathogens (Chun et al., 2017).

Among three insecticides, Acetamiprid was more effective against OYVMD with comparison to the other two insecticides and untreated control. These results are further strengthened by the findings of Gowdar et al. (2007) who observed significant whitefly mortality and YMVD in okra due to acetamiprid sprays. Acetamiprid @ $5 \mathrm{ml} / \mathrm{L}$ proved more effective than other insecticides for controlling whitefly resulting in reduced OYMV disease severity (Yadav et al., 2007). Minimum whitefly infestation was observed in okra fields where new chemistry insecticides were applied (Sarkar et al., 2016). Pawar et al. (2016) stated that after application of neonicotenoids the infestation of sucking insects considerably minimized. Neonicotenoids disturbs the synaptic nerves of the sucking insects resulting in death thus reducing the infestation (Begum and Patil, 2016). The disturbance in synaptic nerves creates stimulation in sucking insect pests which ultimately retarded (Bacci et al., 2007). The insecticides with this mode of action have effective translaminar movement which is absorbed by the insects while sucking from lower sides of the leaves (Natwick et al., 2001). Chandio et al. (2017) concluded that synthetic insecticides like Polo (Diafenthiuron) applied weekly on okra plants, showed the best result to manage whitefly (Bemisia tabaci) population on okra. Kalyan et al. (2017) described significant reduction in whitefly population in Diafenthiuron okra plants. Diafenthiuron disrupts the process of oxidative phosphorylation and interrupts the formation of ATP (Kumar et al., 2019). Sathyan et al. (2016) concluded that Diafenthiuron reduced the whitefly population upto $65 \%$. It reduces the function of mitochondria causing immobility in the insects (Haq et al., 2018). Mortita et al. (2007) described that Pyridine Carboxamide caused significant whitefly mortality due to starvation and convulsions. It alters the feeding behavior of whitefly when it sucks the treated plants (Morita et al., 2014). It blocks the potassium. A type channel which causes failure of nervous system and insect pierce the leaf surface (Jansen et al., 2011). Colomer et al. (2011) declared the flonicamid from Pyridine Carboxamide group as the efficient control of whitefly after repeated experiments.

\section{CONCLUSION}

It is concluded that leaf manure and acetamiprid are more effective in reducing okra yellow vein mosaic virus disease severity and whitefly population.

\section{ACKNOWLEDGEMENT}

The authors acknowledge the cooperation of Chairman of Department of Plant Pathology, University of Agriculture Faisalabad for providing area for research.

\section{AUTHOR'S CONTRIBUTION}

A. Munir: Conducted research

S. Ali: Supervised

M. A. Zeshan: Paper writeup

M. U. Ghani: Supervised

A. A. Khan: Statistical analysis of data

\section{REFERENCES}

Acharya, S., H. P. Mishra and D. Dash. 2002. Efficacy of insecticides against okra jassid (Amrasca biguttula Ishida). Annals of Plant Protection Science, 10 (2): 230-232.

Agyarko, K., P. K. Kwakye, M. Bonsu and B. A. Osei. 2006. Impact of application of neem leaves and poultry manure on nutrient dynamics of a Haplic Acrisol. Archives of Agronomy and Soil Science, 52 (6): 687-695.

Afzal, M., T. Ahmad, and M. H. Bashir. 2002. Relative toxicity of different insecticides against whitefly, Bemisia tabaci (Genn.) and black thrips, Caliothrips indicus on NM-92 mungbean, Vigna radiata (L.). Pakistan Journal of Agricultural Sciences, 39: 224225.

Akinyele, B. O. and T. Temikotan. 2007. Effect of variation in soil texture on the vegetative and pod characteristics of okra (Abelmoschus esculentus L.). International Journal of Agriculture, 2 (2): 165-169.

Amadi, J. E., C. Nnamani, C. O. Ozokonkwo and C. S. Eze. 2014. Incidence and severity of okra (Abelmoschus esculentus L.) fruit rot in Nigeria. International Journal of Current Microbiology Science, 3 (4): 1114-1121.

Bacci, L., A. L. B. Crespo, T. L. Galvan, E. Pereira, M. C. Picanco, G. A. Silva and M. Chediak. 2007. Toxicity of insecticides to the sweet potato whitefly (Hemiptera: Aleyrodidae) and its natural enemies. Pest Management Science: formerly Pesticide Science, 63 (7): 699-706. 
Bassi, D., M. Menossi and L. Mattiello. 2018. Nitrogen supply influences photosynthesis establishment along the sugarcane leaf. Scientific Reports, 8 (1): 1-13.

Begum, K. and S. Patil. 2016. Evaluation of newer molecules of insecticides against sucking pests complex infesting okra. Indian Journal of Applied Research, 6 (2): 10-14.

Calvo, P., L. Nelson and J. W. Kloepper. 2014. Agricultural uses of plant bio stimulants. International Journal of Plant and Soil Science, 383 (1): 3-41.

Chaitanya, G. and A. Kumar. 2018. Efficacy of selected insecticides and neem products against whitefly (Bemisia tabaci) Gennadius of okra (Abelmoschus esculentus L. Moench). Journal of Entomology and Zoology Studies, 6 (4): 115-117.

Chandio, M. A., S. A. Hyder, F. Magsi and S. Mangi. 2017. Comparative efficacy of some bio and synthetic insecticide against Bemisia tabaci on okra crop. Pakistan Journal of Biological Sciences, 60 (1): 117-121.

Chaudhary, A., M. A. Khan and B. Yousaf. 2017. Management of okra yellow vein mosaic virus and its vector through plant extracts. Journal of Microbiology and Plant Pathology, 8 (1): 393-395.

Chun, J. H., S. Kim, M. V. Arasu, N. A. Al-Dhabi, D. Y. Chung and S. J. Kim. 2017. Combined effect of nitrogen, phosphorus and potassium fertilizers on the contents of glucosinolates in rocket salad (Eruca sativa Mill.). Saudi Journal of Biological Sciences, 24 (2): 436-443.

Colomer, I., P. Aguado, P. Medina, R. M. Heredia, A. Fereres and J. E. Belda. 2011. Field trial measuring the compatibility of methoxyfenozide and flonicamid with Orius laevigatus Fieber (Hemiptera: Anthocoridae) and Amblyseius swirskii (Athias-Henriot) (Acari: Phytoseiidae) in a commercial pepper greenhouse. Pest Management Science, 67 (10): 1237-1244.

Fajinmi, A. and C. A. Odebode. 2005. Effect of poultry manure on pepper veinal mottle virus (PVMV), yield and agronomic parameters of pepper (Capsicum annum) in Nigeria. East African Journal of Sciences, 1 (2): 104-111.

FAO, 2018. FaoStat Database. Available http://faostat.fao.org.

Gowdar, S. B., H. H. Ramesh Babu and N. A. Reddy. 2007. Efficacy of insecticides on okra yellow vein mosaic virus and whitefly vector, Bemisia tabaci Genn. Annals of Plant Protection Science, 15 (1): 116-119.
Hassan, M. R., I. Hossain, M. R. Islam and M. A. R. Khokon. 2013. Comparative efficacy of compost, compost tea, poultry litter and bavistin in controlling diseases of chili. Progressive Agriculture, 24 (1): 39-44.

Haq, M. R., R. Javeed, S. Iram, M. A. Rasheed, M. Amjad and F. lqbal. 2018. Effect of diafenthiuron exposure under short and long term experimental conditions on hematology, serum biochemical profile and elemental composition of a non-target organism, Labeo rohita. Environmental Toxicology and Pharmacology, 62: 40-45.

Jansen, R. M. C., J. Wildt, I. F. Kappers, H. J. Bouwmeester, J. W. Hofstee and E. J. van Henten. 2011. Detection of diseased plants by analysis of volatile organic compound emission. Annual Review of Phytopathology, 49: 157-174.

Kalyan, R. K., D. P. Saini, B. M. Meena, P. Abhishek, P. Naruka, S. Verma and S. Joshi. 2017. Evaluation of new molecules against jassids and white flies of Bt cotton. Journal of Entomology and Zoology Studies, 5 (3): 236-240.

Kasai, M. 2008. Regulatory mechanism of photosynthesis that depends on the activation state of rubisco under sinklimitation. International Journal of Agriculture and Biology, 3: 293-287.

Khan, M. A., M. Sajid, Z. Hussain, A. Rab, B. K. Marwat, Fazal-i-Wahid and S. Bibi. 2013. How nitrogen and phosphorus influence the phenology of okra. Pakistan Journal of Botany, 45 (2): 479-482.

Kulkarni, C. S. 1924. Mosaic and other related diseases of crops in the Bombay Presidency. Poona Agriculture College Magazine 16, pp. 6-12.

Kumar, A., R. B. Verma, R. Kumar, S. K. Sinha and $R$. Kumar. 2017. Yellow vein mosaic disease of okra: A recent management technique. International Journal of Plant and Soil Science, 19 (4): 1-8.

Kumar, V., V. Jindal, S. K. Kataria and M. Pathania. 2019. Activity of novel insecticides against different life stages of whitefly (Bemisia tabaci). Indian Journal of Agricultural Sciences, 89 (10): 1599-1603.

Mishra, G. P., B. Singh, T. Seth, A. K. Singh, J. Halder, N. Krishnan, K. Shailesh, Tiwari and P. M. Singh. 2017. Biotechnological advancements and begomovirus management in okra (Abelmoschus esculentus L.) Status and perspectives. Frontiers in Plant Science, pp. 8: 360. 
Morita, M., T. Ueda, T. Yoneda and T. Koyanagi. 2007. Flonicamid, a novel insecticide with a rapid inhibitory effect on aphid feeding. Pest Management Science, 63 (10): 969-973.

Morita, M., T. Yoneda and N. Akiyoshi. 2014. Research and development of a novel insecticide, flonicamid. Journal of Pesticide Sciences, 39 (3): 179-180.

Mubeen, M., Y. Iftikhar, M. I. Ullah, Q. Shakeel, M. Aatif and I. Bilqees. 2017. Incidence of okra yellow vein mosaic disease in relation to insect vector and environmental factors. Environment and Ecology, 35 (3C): 22152220.

Mur, L. A., C. Simpson, A. Kumari, A. K. Gupta and K. J. Gupta. 2017. Moving nitrogen to the center of plant defence against pathogens. Annals of Botany, 119 (5): 703709.

Nagaraju, N., A. Padmaja, G. B. Gowda, R. Pushpa. 2015. Vectors of plant viruses of crop plants in Southeast Asia, New Horizons in Insect Science: Towards Sustainable Pest Management. Springer, pp: 159-176.

Natwick, E. T. 2001. Comparison of neonicotinoid with pyrethroid insecticides for control whitefly in cotton. pp. 802-803. In: Proceeding. Beltwide Cotton Conference Jan. 9-13. Anaheim, CA. Natl. Cotton Council. Am. Memphis, TN.

Pagire, K. S., V. U. Sonalkar, P. Dipali, V. V. Thakare, A. Kalpande and V. M. Chavan. 2017. Effectiveness of insecticidal sprays against whitefly checking yellow vein mosaic virus (YVMV) incidence in okra (Abelomoschus esculentus (L.) Moench. International Journal of Current Microbiology and Applied Sciences, 6 (2): 362-366.

Pawar, S. A., P. R. Zanwar, S. G. Lokare, R. P. Dongarjal and M. M. Sonkamble. 2016. Efficacy of newer insecticides against sucking pests of okra. Indian Journal of Entomology, 78 (3): 257-259.

Rahim, S. and S. Dawar 2015. Seed-borne mycoflora associated with okra. [Abelmoschus esculentus (L.) Moench]. Pakistan Journal of Botany, 47 (2): 747-751.

Riyana, D., Y. Widiyastuti, H. Widodo, E. Purwanto and Samanhudi. 2018. Effect of manure and plants spacing on yield and flavonoid content of Elephantopus scaber L. Earth and Environmental Science, 142 (1): $1-8$.

Roy, B., B. Chakraborty, A. Mitra, S. Sultana and A. R. Sherpa. 2015. Natural occurrence of bhendi yellow vein mosaic virus on Litsea spp. in India. New Disease Reports, 31: 7.

Sana, N., A. Shoaib, A. Javaid and Nafisa. 2015. Effect of neem leaves as soil amendment on southern blight disease, growth and physiology of chili. Pakistan Journal of Phytopathology, 27 (2): 115-120.

Sanwal, S. K., V. Venkataravanappa and B. Singh. 2016. Resistance to bhendi yellow vein mosaic disease: A review. Indian Journal of Agricultural Sciences, 86 (7): 835843.

Sarkar, S., S. Patra and A. Samanta. 2016. Efficacy of different biopesticides against sucking pests of okra (Abelmoschus esculentus (L.) Moench. Journal of Applied and Natural Science, 8 (1): 333-339.

Sathyan, T., N. Murugesan, K. Elanchezhyan, A. Stephen. J. Raj and G. Ravi. 2016. Efficacy of synthetic insecticides against sucking insect pests in cotton, Gossypium hirsutum L. International Journal of Entomology Research, 1: 16- 21.

Saurabh, A., N. Kudada and S. K. Singh. 2016. An approach to management of yellow vein mosaic of okra. Environment and Ecology, 4: 1368-1371.

Sharma, D., A. Maqbool, V. V. S. Jamwal, K. Srivastava and A. Sharma. 2017. Seasonal dynamics and management of whitefly (Bemisia tabaci Genn.) in tomato (Solanum esculentum Mill.). Brazilian Archives of Biology and Technology, 60.

Singh, S., S. Inamdar, M. Mitchell and P. McHale. 2014. Seasonal pattern of dissolved organic matter (DOM) in watershed sources: Influence of hydrologic flow paths and autumn leaf fall. Biogeochemistry, 118 (1-3): 321-337.

Steel, R. G. D., J. H. Torrie and D. Dickey. 1997. Principles and Procedures of Statistics. A biometric approach, $3^{\text {rd }}$ Ed. McGraw Hill Book Co. Inc. New York.

Thumar, R. T., P. K. Borad, N. P. Pathan, T. M. Bharpoda, M. M. Saiyad and H. K. Chaudhary. 2018. Bio-efficacy of diafenthiuron $25 \%$ and pyriproxyfen $5 \%$ SE against sucking insect pests of Bt cotton. Journal of Entomology and Zoology Studies, 6 (5): 1024-1029.

Venkataravanappa, V., L. N. C. Reddy, S. Jalali and K. M. Reddy. 2012. Molecular characterization of distinct bipartite begomovirus infecting bhendi (Abelmoschus esculentus L.) in India. Virus Genes, 44 (3): 522-535. 
Yadav, U. S., A. Yadav and S. S. Prasad. 2007. Efficacy and economics of certain new insecticides on vector whitefly, Bemisia tabaci (Genn.) causing yellow vein mosaic disease in mesta. Souvenif $7^{\text {th }}$ National Symp on plant protection optionsImplementation and Feasibility, P. 750.
Yadav, R. N., H. L. Bairwa and M. K. Gurjar. 2017. Response of garlic (Allium sativum L.) to organic manures and fertilizers. International Journal of Current Microbiology and Applied Sciences, 6 (10): 4860-4867.

(Received: May 31, 2019; Accepted: June 16, 2020) 